\title{
Zinc Finger MIZ Domain-Containing Protein 1
}

National Cancer Institute

\section{Source}

National Cancer Institute. Zinc Finger MIZ Domain-Containing Protein 1. NCI Thesaurus.

Code C119668.

Zinc finger MIZ domain-containing protein 1 (1067 aa, 115 kDa) is encoded by the human ZMIZ1 gene. This protein plays a role in the regulation of transcription by mediating the sumoylation of androgen receptor. 